\title{
TEMA DAN NILAI MORAL DALAM EMPAT CERITA PENDEK TERBITAN SURAT KABAR MANUNTUNG DI KALIMANTAN TIMUR
}

\section{THEMES AND MORAL VALUES IN FOUR SHORT STORIES OF MANUNTUNG NEWSPAPER IN EAST KALIMANTAN}

\author{
Yudianti Herawati \\ Kantor Bahasa Provinsi Kalimantan Timur \\ Jalan Batu Cermin 25 Sempaja, Samarimda Utara \\ Posel: yudianti_bayu@yahoo.com
}

*)Naskah diterima: 3 Mei 2021; direvisi: 3 Mei 2021; disetujui: 28 Mei 2021

\begin{abstract}
Abstrak
Tujuan penelitian ini untuk mendeskripsikan struktur cerita dalam empat cerpen terbitan surat kabar harian Manuntung periode 1988 berkaitan dengan tema dan nilai moral. Masalah dalam penelitian ini meliputi (1) bagaimana bentuk identifikasi cerita dalam keempat cerpen yang terbit di Manuntung, (2) bagaimanakah tema dalam keempat cerpen yang terbit di Manuntung, dan (3) bagaimana pula nilai-nilai moral dalam keempat cerpen yang terbit di Manuntung. Penelitian ini menggunakan kualitatif dengan memanfaatkan teknik deskripsi, sedangkan teori yang digunakan adalah pendekatan intrinsik. Teknik analitik juga digunakan untuk menentukan makna isi cerita dalam cerpen-cerpen tersebut sebagai objek penelitian. Hasil penelitin menunjukkan bahwa tema dalam keempat cerita pendek terbitan surat kabar Manuntung periode 1988 di Kalimantan Timur (1) memiliki perwatakan dan karakteristik penceritaan yang berbeda, dan (2) nilai moral dalam cerpen-cerpen itu sebagai cerminan kehidupan yang dialami masyarakat dengan latar, waktu, dan lingkungan tertentu yang melatarbelakangi terjadinya peristiwa di lingkungan sosial dan budaya di Kalimantan Timur.
\end{abstract}

Kata kunci: intrinsik, nilai, moral, cerpen

\begin{abstract}
The purpose of this study is to describe the structure of the story related to moral themes and values in four short stories of Manuntung daily newspaper in 1988. It discusses about (1) forms of story identification in Manuntung's four short stories, (2) themes in Manuntung's four short stories, and (3) moral values in Manuntung's four short stories. This research is qualitative. It uses descriptive techniques and intrinsic approach. Analytical techniques are also used to determine the meaning of the story content in the short stories as the object of research. The results of this study indicate that the themes in those four short stories have different narrative characteristics and personalities, while the moral values in those short stories reflect the community's life experience under certain background, time, and environment bringing about events in the social and cultural environment in East Kalimantan.
\end{abstract}

Keywords: intrinsic, value, moral, social, culture 


\section{PENDAHULUAN}

Karya sastra memiliki peranan yang cukup besar dalam membentuk karakter dan kepribadian seseorang. Pada hakikatnya, karya sastra mengajarkan pengalaman hidup dan kehidupan pelakunya. Melalui karya sastra manusia dapat memeroleh kekayaan batin. Rahmanto (2005: 24) mengatakan bahwa seseorang yang telah mendalami sastra biasanya memiliki perasaan yang lebih peka untuk menunjukkan sesuatu yang bernilai atau tidak bernilai. Pada intinya, manusia yang mendalami sastra dengan baik akan mampu menghadapi masalah-masalah hidupnya dengan pemahaman, wawasan, toleransi, dan rasa simpati yang mendalam. Pada dasarnya, sastra tidak dapat dipisahkan dari kehidupan masyarakat, baik kehidupan masa lampau maupun masa kini. Artinya, sastra menjadi bagian yang tidak dapat dipisahkan dari kehidupan manusia sejak dahulu hingga kini. Karya sastra yang hidup dan berkembang pada masyarakat pendukungnya dapat dibedakan menjadi cerita pendek, puisi, novel, drama, cerita bersambung, dan lain sebagainya.

Kehadiran cerpen Indonesia tidak terlepas dari peran media massa. Cerpen-cerpen yang terbit dalam surat kabar banyak dipengaruhi oleh dinamika perubahan yang terjadi di masyarakat, baik kehidupan manusia, kesantunan sebuah masyarakat, peperangan, konflik ideologi, maupun trauma yang mewarnai tulisan-tulisan pengarang. Artinya, surat kabar menjadi sarana aktualisasi diri pengarang dalam memperkenalkan karya sastra yang tulisnya agar dapat diapresiasi khalayak atau penikmat sastra (Effendy, 2011: 49). Oleh karena itu, peran strategis surat kabar dalam memopulerkan sastra dimanfaatkan para penulis di Indonesia, termasuk Kalimantan Timur. Bahkan, periodesasi sastra Indonesia di Kalimantan Timur dapat diketahui melalui karya-karya yang pernah terbit dalam surat kabar.
Perkembangan sastra Indonesia di Kalimantan Timur dimulai pada akhir tahun 1940-an, tepatnya sejak berdiri koran Masjarakat Baroe yang terbit 1 Agustus 1946. Para sastrawan mulai menerbitkan puisi melalui surat kabar sejak tahun 1946 dalam koran Masjarakat Baroe. Hal itu menunjukkan bahwa sastra Indonesia (puisi dan cerpen) di daerah cenderung lebih dahulu muncul di media massa sebelum terbitnya buku atau antologi. Sastrawan yang lebih dahulu memuat karya-karyanya di majalah Pandji Poestaka adalah cerpen M. Kasim “Teman Duduk dan Kawan Bergelut" karya Suman Hs. Selain itu, ada pula karya-karya Haji Moekti, R.M. Tirtio Adhi Soerjo, Semaoen, dan Mas Marco Kartodikromo yang dimuat secara bersambung di koran Medan Prijaji dan Sinar Hindia pada tahun 1900. Awal munculnya penyair dan sastrawan di Kalimantan Timur itu dianggap sebagai pembuka jalan bagi sastrawan dan penyair yang muncul berikutnya, di antaranya Ahmad Dahlan (nama samaran D. Adham), Suhana (nama samaran Muhran Ismaiel), Oemarmaiyah E.Hs., Burhan Dahlan, Maswan Dachri (nama samaran Cupido Andus), Haji Amir, Mansyah Usman (nama samaran M. Faried), Rivai Ahmad, M. Saleh Koeman, Marhaen, Elang Kait, Marakarma, A. Jazidi, Ridwan Majedi, dan lain-lain. Kemudian, pada periodesasi berikutnya, sastra Indonesia di Kalimantan Timur mulai menggeliat sejak munculnya harian Manuntung dan media massa lainnya, seperti Meranti, Kaltim Post, Suara Kaltim, Samarinda Post, Membangun Bumi Etam, dan Tribun Kaltim. Surat kabar harian tersebut memiliki andil yang cukup penting dalam penerbitan sastra di Kalimantan Timur (Herawati, 2020: 105). Selain itu, karya sastra digairahkan pula dengan munculnya komunitas. Sejumlah cerpen yang ditulis pengarang telah dipopulerkan dalam bentuk penerbitan antologi cerita pendek yang dilakukan oleh beberapa komunitas sastra di 
Kalimantan Timur (Rampan, 2011: $105-$ 106).

Berdasarkan uraian tersebut, tujuan penelitian ini untuk mendeskripsikan struktur cerita dalam empat cerpen terbitan surat kabar harian Manuntung periode 1988, yaitu tema dan nilai moral. Keempat cerpen itu adalah (1) "Dermaga Biru” Karya Sukardhi Wahyudi (Juli 1988), (2) “Di Atas Tempaan Lalah" Karya Iin E Birawono (Oktober 1988), (3) "Dari Sebuah Kegagalan" Karya Ifta Larisya (November 1988), dan (4) "Buntut" Karya Roedy Rachmaddi Masykoer Boenna (Desember 1988). Selain itu, penelitian ini diharapkan dapat membangun sikap masyarakat agar dapat menghargai dan bangga terhadap cerpen-cerpen yang terbit pada media massa di Kalimantan Timur.

Masalah dalam penelitian ini mendeskripsikan unsur instrinsik dan ekstrinsik dalam cerpen terbitan surat kabar harian Manuntung periode 1988 terutama analisis tema dan nilai moral. Rumusan masalah meliputi (1) bagaimana bentuk indentifikasi cerita dalam keempat cerpen yang terbit di Manuntung, (2) bagaimanakah tema dalam keempat cerpen yang terbit di Manuntung, dan (3) bagaimana pula nilai-nilai moral dalam keempat cerpen yang terbit di Manuntung.

\section{LANDASAN TEORI}

Cerita pendek atau cerpen merupakan jenis karya sastra berbentuk prosa yang menggambarkan kisah atau cerita tentang kehidupan manusia serta diperankan oleh tokoh-tokoh imajiner atau tokoh-tokoh faktual yang ditulis berdasarkan perenungan, penghayatan, dan penjiwaan pengarangnya sehingga menghasilkan nilai-nilai yang bermakna. Cerpen dapat berbentuk cerpen remaja, politik, religius, dan lain-lain.

Sebagai salah satu jenis karya sastra, cerita pendek dapat juga dijadikan sarana untuk menuangkan ide-ide kreatif dan imajinatif dari pengarang. Melalui unsur intrinsik analisis cerita akan lebih bermakna, khususnya yang berkaitan dengan tema. Menurut Stanton (2012: 36-37), tema merupakan aspek cerita yang sejajar dengan 'makna' dalam pengalaman manusia; suatu pengalaman yang dapat diingat. Ada banyak cerita yang menggambarkan dan menelaah kejadian atau emosi yang dialami manusia seperti cinta, derita, rasa takut, kedewasaan, keyakinan, penghianatan manusia terhadap diri senndiri, disilusi, atau usia tua. Sementara itu, unsur ekstrinsik yang berkaitan dengan nilai-nilai moral yang ada dalam karya sastra merupakan pesan tidak langsung dari pengarang. Hal itu sejalan dengan pendapat Kenny dalam (Nurgiyantoro, 2013: 430) yang mengemukakan bahwa moral dalam karya sastra biasanya dimaksudkan sebagai suatu saran yang berhubungan dengan ajaran moral tertentu, bersifat praktis, dan dapat diambil melalui cerita yang bersangkutan oleh pembaca. Selanjutnya, dalam Kamus Besar Bahasa Indonesia (2008: 929) menjelaskan bahwa nilai moral adalah "ajaran baik dan buruk yang diterima secara umum mengenai perbuatan, sikap, kewajiban, akhlak dan budi pakerti".

Berdasarkan beberapa pendapat tersebut, untuk memahami unsur instrinsik dalam cerpen terbitan surat kabar Manuntung, penelitian ini lebih mengarah pada pendapat Stanton. Menurutnya, tema merupakan aspek cerita yang sejajar dengan 'makna' dalam pengalaman manusia yang selalu diingat. Begitu pula dengan unsur ekstrinsik dalam keempat cerpen itu terdapat nilainilai moral sebagai sesuatu yang ingin disampaikan oleh pengarang kepada pembaca. Tentu saja berkaitan dengan makna yang terkandung dalam karya sastra. Melalui suatu cerita, sikap, dan tingkah laku tokoh-tokoh, pembaca dapat memahami pesan moral yang disampaikan pengarang (Wicaksono, 2017: 323). 


\section{METODE PENELITIAN}

Jenis penelitian ini menggunakan metode kualitatif dan metode deskripsi, sedangkan teori yang digunakan adalah pendekatan intrinsik. Teknik analisis deskriptif digunakan untuk mendeskripsikan data-data cerpen yang telah diperoleh di surat kabar Manuntung. Selain itu, teknik analitik juga digunakan untuk menentukan makna isi cerita dalam cerpen-cerpen tersebut sebagai objek penelitian.

Pengumpulan dan analisis data melalui data-data pustaka dan nonpustaka. Secara pustaka, data penelitian diperoleh pada data-data tertulis, yakni dokumen tertulis seperti buku, majalah, surat kabar, dan dokumen-dokumen tertulis lainnya. Sementara itu, data nonpustaka diperoleh melalui metode kuesioner dan wawancara. Metode nonpustaka itu digunakan untuk menunjang data yang didapatkan dari dokumen tertulis. Pengumpulan data dengan metode nonpustaka berupa wawancara dan kuesioner dilakukan terhadap pengarang atau pihak-pihak tertentu yang dipandang memiliki pengetahuan mengenai cerpen di Kalimantan Timur. Adapun sumber data diperoleh dari surat kabar harian Manuntung yang terbit tahun 1988.

\section{HASIL DAN PEMBAHASAN}

\subsection{Identifikasi Cerita}

Sebagai salah satu jenis karya sastra, cerita pendek dapat dijadikan sarana untuk menuangkan ide-ide kreatif dan imajinatif dari pengarang. Dalam karya cerpen banyak mengandung nilai estetis, budaya, sosial, nilai moral, dan nilai-nilai religius (keagamaan). Selain itu, karya sastra berupa cerita pendek yang tumbuh dan berkembang di Indonesia tidak dapat dipisahkan dari media massa. Peran media massa memiliki andil besar terhadap penciptaan dan penerbitan sastra Indonesia termasuk di
Kalimantan Timur. Surat kabar Manuntung merupakan koran yang menampilkan cerpen-cerpen karya pengarang Kalimantan Timur dari berbagai daerah. Cerpen-cerpen yang terbit dalam surat kabar itu memiliki ragam karakter yang dapat memerkaya wawasan generasi muda dalam menikmati keberagaman nilai dalam karya sastra.

Berdasarkan hal itu, perlu adanya pendokumentasian terhadap cerita pendek Indonesia di Kalimantan Timur agar masyarakat dapat memperoleh manfaat dari kreativitas pengarang dan karya-karyanya. Oleh karena itu, pada bagian ini akan diuraikan secara singkat terkait identifikasi cerita dalam keempat cerpen terbitan Manuntung periode 1988.

\subsubsection{Cerpen "Dermaga Biru" Karya Sukardhi Wahyudi}

Senja itu, tampak seorang pemuda sedang duduk termangu di ujung demaga sambil memandang ke arah kapal yang berlayar di Sungai Mahakam. Pemuda itu bernama Yudhi. Ia sudah tiga hari duduk di dermaga itu. Entahlah, siapa yang sedang dinantikannya. Dari kejauhan terlihat sebuah kapal besar telah meninggalkan demaga dan berlayar menuju laut lepas. Tiba-tiba seorang Bapak setengah tua menghampiri Yudhi dan duduk di sampingnya. Kemudian, mereka berkenalan. Bapak itu mengenalkan diri bernama Bondang. Keduanya larut dalam perbincangan tentang keadaan masing-masing. Bercerita tentang Sungai Mahakam, burung-burung, politik, perekonomian, sosial, dan filsafat serta cinta. Keduanya tertawa lepas tanpa beban. Tibatiba obrolan keduanya terhenti karena ada sebuah kapal yang datang dari Muara Muntai dan merapat di dermaga. Pak Bondang berdiri dan berjalan menghampiri kapal itu. Tatapannya meraba keseluruh kapal. Penumpang satu per satu turun dan berhamburan di dermaga. Para penjemput dan kuli panggul juga berdatangan men- 
dekati kapal itu. Yudhi menghampiri Pak Bondang yang sibuk mengangkat sebuah bungkusan dan koper. Yudhi ingin membantu Pak Bondang mengangkat koper dan bungkusan itu, namun ditolak oleh Pak Bondang. Kemudian, Pak Bondang menarik tangan Yudhi lalu mengenalkan seorang gadis cantik, anak Pak Bondang padanya. Sontak gadis itu mendekati Yudhi, keduanya berjabat tangan lalu berpelukan. Pak Bondang terperanjak kaget menyaksikan adegan tersebut. Ternyata anak gadisnya dan Yudhi adalah sepasang kekasih yang selama ini dinantikan kedatangannya oleh Yudhi.

\subsubsection{Cerpen "Di Atas Tempaan Lelah" Karya Iin E Birawono}

Masa OSPEK bagi mahasiswa baru pada Fakultas Kehutanan di sebuah perguruan tinggi Kota Samarinda telah memasuki hari kelima. Masa itu akan segera berakhir. Mereka serentak memasang tenda, membuat api unggun, dan mempersiapkan kebutuhan berkemah lainnya. Dyera Costulata adalah mahasiswa baru yang sedang mengikuti orientasi di kampus barunya. Ia seorang gadis manis, manja, dan sangat ketergantungan pada orang tua dan kakaknya. Subuh itu, Dyera sangat ketakutan dengan suasana yang belum pernah ia alami sebelumnya. Ia teringat perhatian dan kasih sayang Mama dan kakaknya, Heri. Air mata Dyera membasahi pipi yang telah dingin oleh embun. Dyera merasa tidak tahan berada di tempat sepi itu. Tiba-tiba Dyera tersentak, seorang raka (sapaan kakak tingkat) memanggilnya. Dyera hanya tertunduk menahan isak tangis. Raka tidak hentihentinya membentak dan menghardik Dyera karena tidak menjawab semua pertanyaan yang di lontarkannya. Siang hari, Kak Daniel memanggil Dyera dengan ramah. Tidak terlihat wajah seram yang dihadapi Dyera subuh itu. Kak Daniel yang tak lain adalah Raka menanyakan asal sekolah
Dyera. Ternyata Daniel dan Dyera satu sekolah di SMA Negeri 2 Samarinda. Keduanya memiliki kesamaan hoby membuat puisi di majalah dinding. Dyera yang lebih dulu mengenal Daniel dengan nama samara Leo sangat terkejut. Selama ini, Dyera mengagumi sosok Leo yang pandai membuat puisi indah dan romantis. Namun, ia belum pernah bertemu dengan Leo.Ternyata Leo adalah Daniel. Betapa gembiranya hati Dyera dapat bertemu dangan pujaan hati yang diimpikannya. Setelah pertemuan itu, Dyera bersemangat menjalani orientasi tanpa mengeluh lagi. Ia benjanji akan belajar mandiri, tidak ingin manja, dan ketergantungan pada Mama dan Kak Heri.

\subsubsection{Cerpen "Dari Sebuah Kegagalan" Karya Ifta Larisya}

Ara adalah seorang gadis yang baru saja menamatkan sekolah menengah di Kota Samarinda. Keinginannya melanjutkan pendidikan di sebuah perguruan tinggi negeri sangat antusias. Ia berharap dapat berkuliah demi mencapai cita-cita dan masa depannya. Namun, takdir berkata lain. Berulang kali Ara mengikuti tes UMPTN agar bisa masuk ke perguruan tinggi negeri, tetapi selalu gagal sehingga Ara menjadi putus asa. Gairah hidupnya hampa. Ara tidak mau membebani orang tuanya di kampung, jika ia masuk perguruan tinggi swasta karena biayanya cukup mahal. Suatu hari, Ara bertemu dengan Tia, teman sekolah masa SMA. Tia menyarankan agar Ara melamar pekerjaan di sebuah perusahaan swasta yang ada di Kota Samarinda. Tawaran Tia diterima Ara dengan gembira. Ara bergegas menyiapkan berkas untuk mengikuti wawancara di perusahaan swasta itu. Hatinya gundah. Rasa takut dan was-was menghantui pikiran Ara. Hingga akhirnya, ia berhasil melewati masa-masa tegang dan menunggu hasil wawancara tersebut. Untuk mengisi hari-hari, Ara membantu tantenya membuka usaha catering, yakni menerima 
pesanan makanan berbagai hajatan, baik pesta kawinan maupun pesta lainnya. Tidak terasa sudah satu bulan Ara membantu tantenya membuka usaha catering. Ara hampir lupa dengan lamaran kerja di perusahaan swasta itu. Suatu hari, sepulang belanja kebutuhan catering, Ara melihat Tia duduk diteras rumah tante menunggu kedatangannya. Tiba-tiba Tia menyodorkan surat padanya. Ara langsung membuka isi surat itu yang menyatakan bahwa ia diterima bekerja di perusahaan swasta tersebut. Ara sangat bersyukur, ternyata Tuhan telah membukakan jalan yang lebih baik untuk masa depannya. Impian menjadi mahasiswa dan meraih cita-cita tidak pernah diharapkannya lagi.

\subsubsection{Cerpen "Buntut" Karya Roedy Rachmaddi Masykoer Boenna}

Marno adalah seorang pemuda pengurus karang taruna di sebuah kampung, Kota Balikpapan. Mario dikenal rajin, tegas, disiplin serta bertanggung jawab. Marno memiliki seorang sahabat bernama Buddi. Kedua sahabat ini saling bahu-membahu dalam kegiatan karang taruna di kampungnya. Marno memiliki kebiasaan bermain buntut atau togel. Tiap kali memasang buntut, Mario selalu beruntung. Sekali pun ia tidak pernah kalah atau gagal. Wajar, jika ia menyebut dirinya adalah Marno Beruntung. Jika menang, Marno sering mengajak sahabatnya, Buddi dan teman-teman taruna untuk makan serta nonton film di bioskop. Marno memiliki seorang istri bernama Pariyem, gadis cantik, kembang desa, dan selalu menjadi rebutan pemuda kampung termasuk Buddi. Marno sangat beruntung dapat mempersunting Pariyem. Mereka menikah di usia yang sangat muda. Sebagai seorang istri, Pariyem sangat penurut dan patut pada suaminya sehingga apa pun yang dilakukan oleh suaminya, ia menerima. Marno sangat membanggakan istrinya sebagai wanita setia. Keduanya hudup rukun tanpa cela. Namun, kebiasaan Marno bermain buntut membuat istrinya kesal dan marah. Berbagai nasihat dilontarkan istri dan sahabatnya tidak pernah digubris Marno. Pariyem pun tidak sanggup untuk bertahan dan memilih meninggalkan Marno. Waktu berlalu dengan cepatnya, Buddi hampir tidak mengetahui lagi tentang Marno. Suatu hari, Buddi mampir makan di warung mbok Ijah. Mbok Ijah menceritakan kondisi Marno menjadi gila setelah di tinggal istrinya. Hidup Marmo benarbenar hancur. Apalagi, tempat perjudiannya digebrek polisi. Tidak ada yang mampu menyelamatkan Marmo dalam keterpurukan. Marno sering melamun dan menyeloteh sendiri. Ia sering mengucap kata luput... luput.... oh.... buntut. "Ya, Marno telah gila akibat permainan yang menyesatkannya, yakni buntut".

\subsection{Tema}

Dalam unsur intrinsik, tema adalah ide yang mendasari suatu cerita. Tema dapat dipandang sebagai gagasan dasar secara umum yang tertuang dalam karya sastra. Gagasan itu ditentukan sendiri oleh pengarang untuk mengembangkan suatu cerita. Artinya, tema merupakan ide atau gagasan cerita yang mendasari dan menopang suatu cerita. Kemunculan tema tidak secara langsung dituliskan pengarang, melainkan pembaca yang dituntut untuk menentukan tema dalam cerita itu. Dengan kata lain, tema merupakan aspek cerita yang sejajar dengan makna dalam pengalaman manusia, yang menjadikan suatu pengalaman begitu diingat dalam aspek-aspek kehidupan sehingga tema menjadi elemen yang relevan bagi setiap peristiwa dan detail sebuah cerita. Berkaitan dengan hal itu, tema yang disajikan dalam keempat cerpen terbitan surat kabar Manuntung periode 1988 memiliki karakteristik penceritaan yang unik dan beragam. Adapun tema dalam 
cerpen (1) "Dermaga Biru", (2) "Di Atas Tempaan Lalah", (3) “Dari Sebuah Kegagalan", dan (4) "Buntut" dapat diuraikan sebagai berikut.

\subsubsection{Cerpen "Dermaga Biru"}

Cerpen “Dermaga Biru” Karya Sukardhi Wahyudi yang dimuat dalam surat kabar Manuntung, Kamis 21 Juli 1988, mengangkat tema penantian dengan menggunakan alur maju. Kisah ini berawal dari seorang pemuda yang di rundung kegelisahan menanti kedatangan seseorang. Setiap hari pemuda bernama Yudhi itu duduk di ujung sebuah dermaga, tepatnya di dermaga biru Sungai Mahakam. Tiba-tiba seorang Bapak setengah tua menghampiri dan mengenalkan diri pada pemuda itu. Pemuda itu pun terkejut dan seketika membuyarkan lamunannya. Keduanya larut dalam perbincangan sambil mata keduanya memandang ke arah Sungai Mahakam, seakan-akan sedang menantikan kedatangan seseorang.

"Mau mudik kemana nak ? Sudah tiga hari ini saya lihat nak duduk disini. Atau ada yang ditunggu barangkali ?" kata orang setengah baya itu sambil duduk di samping pemuda itu. "Tidak juga pak, kebetulan saya lagi suka menikmati senja di dermaga ini" jawab lelaki muda itu sopan.

"Oh ya, boleh saya tahu siapa nama nak". "Yudhi pak" potong lelaki muda itu. "Oh Yudhi..., nak Yudhi begitu "lalu tertawa renyah" Kalau saya Bondang" lanjut orang setengah baya itu. Dan mereka pun saling berjabatan tangan (Wahyudi, 1988: VI).

Dalam kutipan tersebut, tema yang dimunculkan adalah adegan percakapan dua orang laki-laki yang berbeda usia yang penuh kasih sayang. Keduanya memiliki tujuan dan hasrat yang sama, yakni menantikan kedatangan seorang yang selama ini didambakannya. Yudhi berperan sebagai tokoh utama, sedangkan Pak Bondang berperan sebagai tokoh protagonis. Keduanya larut dalam situasi yang diperbincangkan. Pada akhir cerita pengarang menyelesaikannya dengan kebahagiaan. Seorang gadis cantik menghampiri kedua lelaki itu dengan penuh kehangatan. Ternyata gadis itu adalah anak Pak Bondang yang juga kekasih Yudhi.

\subsubsection{Cerpen "Di Atas Tempaan Lelah"}

Cerpen “Di Atas Tempaan Lelah” karya Iin E Birawono yang dimuat dalam surat kabar Manuntung, Rabu 12 Oktober 1988 mengangkat tema sebuah kegelisahan dan pengharapan. Cerpen ini melukiskan suasana perkemahan bagi mahasiwa baru yang dinamakan Orientasi Studi dan Pengenalan Kampus (OSPEK). Munculnya tema itu berawal dari kegelisahan seorang mahasiwa baru bernama Dyera. Dyera gadis manis, manja, cengeng, dan sangat ketergantungan pada Ibu dan Kakaknya. Pada masa ospek banyak hal ganjil yang dihadapi Dyera. Ia sangat tidak terbiasa tidur di dalam tenda, pakaian kusut, serta rambut yang tidak terurus. Semua itu sangat menyiksa batinnya. Ia membayangkan kedamain ketika bersama Ibu dan Kakaknya di rumah. Daniel yang disapa sebagai Raka (kakak tingkat) berhasil mengubah kepribadian Dyera yang manja dan cengeng itu. Pertemuan Dyera dengan Daniel, yang sesungguhnya memiliki nama samaran Leo, membuat Dyera terkejut.

Aku ingat kamar tidur yang hangat, aku ingat Mama dan Bang Heri yang selalu memanjakanku, aku ingat segalanya yang enak, yang selalu membuatku berada dalam kenyamanan. Aku ragu pada kemampuanku, sanggupkah kujalani hari-hari nanti..... ah momok besar telah melanda diriku.

Aku nyaris seperti boneka yang tak bernyawa, seperti manusia terjajah 
yang telah kehilangan haknya. Tubuhku begitu kusam dan lesu, pakaianku kumal dan dekil, rambutku kusut karena tak sempat dibenahi dan yang jelas tatap mataku jauh dari yang namanya riang.

“Daniel ternyata Leo"? Aku tersentak, Leo leleki misterius yang selama ini begitu aku kagumi hadir dihadapanku. Dyera menarik napas. Kayalannya pada sosok Leo menjadi kenyataan. Pertemuan itu begitu berarti dalam diri Dyera. Leo mampu menjadikannya tidak manja lagi (Birawono, 1988: VI).

Dalam kutipan tersebut, pengarang menggunakan alur maju. Kisah dari awal sampai akhir mengalir mengikuti rentetan peristiwa. Tokoh Dyera berkepribadian penakut dan gampang rapuh sehingga ia merasa tidak sanggup menjalankan hidup tanpa orang tua dan kakaknya. Pertemuannya dengan Daniel yang sebenarnya bernama samaran Leo menjadikan Dyera bangkit dan belajar menata kepribadian untuk lebih baik dan tidak mudah rapuh. Dalam cerpen ini pengarang menyelesaikan bagian akhir cerita (resolusi) dengan cara penyelesaian masalah. Tokoh utama (Dyera) kembali menggeluti kegemarannya membuat puisi untuk mengungkapkan perasaannya pada Leo (Daniel). Sementara itu, Leo pun secara diam-diam semakin mengagumi sosok Dyera yang manis dan manja. Akhirnya, Leo merasa menemukan tambatan hati yang selama ini dicurahkan lewat puisipuisi romantisnya.

\subsubsection{Cerpen "Dari Sebuah Kegagalan"}

Cerpen “Dari Sebuah Kegagalan” karya Ifta Larisya yang dimuat dalam Manuntung, Kamis 3 November 1988, mengangkat tema kegagalan. Tema ini diawali dari keputusasaan seorang gadis yang ingin meraih harapan dan impiannya. Selepas SMA, tokoh utama (Ara) berkeinginan melanjutkan pendidikan ke perguruan tinggi negeri. Alur yang digunakan dalam cerita ini adalah alur maju. Tokoh utama berjuang sekuat tenaga mengikuti tes (sipenmaru) masuk perguruan tinggi negeri, tetapi berulang-ulang pula mengalami kegagalan. Ara hanya dapat pasrah, putus asa, dan iba pada orang tua yang mengharapkannya masuk perguruan tinggi negeri. Dalam pikiran Ara, tidak mungkin orang tuanya sanggup membiayai kuliah di perguruan tinggi swasta karena akan mengeluarkan dana yang cukup tinggi.

"Oh Tuhan, benarkah semua ini?" aku bersusah payah mengerjakan soalsoal Sipenmaru yang begitu rumit, dan aku yakin akan berhasil. Tapi nyatanya? Tak tertera nomorku, namaku. Huh! Dengan geram kurobek-robek lembaran bisu yang tak berdosa ini, hingga hancur berkeping-keping.

"Ya, aku memang gagal dalam Sipenmaru, mungkin itu takdirku, tapi kini toh aku diterima bekerja, aku yakin inilah hikmahnya, rupanya Tuhan telah menggariskan jalan hidupku demikian. Terima kasih Tuhan, aku langsung sujud syukur, Engkau memang Maha Mendengar semua pinta hambaMu" (Larisya, 1988: VI).

Dalam kutipan tersebut, pengarang menggambarkan kerapuhan tokoh utama ketika mengalami kegagalan dengan menggunakan alur maju. Ara merasa kesal, protes, dan tidak percaya bahwa Tuhan telah menggariskan takdirnya untuk gagal dan gagal. Sebagai sahabat, Tia selalu menyemangati dan mendukung Ara agar tidak berputus asa. Tia pun menawarkan pekerjaan pada Ara. Berkat kesabaran dan usahanya, akhirnya Ara diterima bekerja di sebuah perusahaan swasta di Samarinda. 
Pada akhir cerita pengarang menyelesaikan cerita (resolusi) dengan cara penyelesaian masalah. Tokoh utama disadarkan pada sebuah pernyataan bahwa kegagalan itu tidak pernah ada jika kita pandai bersyukur dan berusaha.

\subsubsection{Cerpen "Buntut"}

Cerpen "Buntut" karya Roedy Rachmaddi Masykoer Boenna yang dimuat dalam Manuntung, Rabu 28 Desember 1988, mengangkat tema sosial. Tema ini diawali dengan kebiasaan seorang lelaki yang hobi bermain judi, buntut, atau togel. Lelaki itu bernama Marno yang juga aktif dalam organisasi karang taruna di kampung. Ia berjiwa sosial, disiplin, dan bertanggung jawab. Sebagai seorang pemimpin, Marno menjadi panutan dan teladan bagi teman-temanya. Namun, kebiasaan bermain buntut telah menghancurkan dirinya. Ia menjadi seorang yang bersifat sombong, angkuh, egois, serta tidak memiliki jati diri. Bahkan, rumah tangganya turut hancur. Istri yang sangat dicintai telah pergi meninggalkannya. Marno memiliki dua orang sahabat bernama Buddi dan Mbok Ijah. Mbok Ijah dan Buddi sering menasihati Marno agar meninggalkan kebiasaannya bermain buntut. Namun, Marno tidak pernah menggubrisnya. Hingga akhirnya Marno menjadi kecanduan, tidak perduli lagi dengan keluarganya.

"Begitu itu kebiasaan mas Marno yang tidak bisa diubah" Pariyem suatu kali mengadu kepadaku.

"Ya... ngga apa-apa to Yem!"

"Wong mas Marno tidak mengganggu ketentraman umum" jelasku.

"Tapi itu judi mas...!" Potong Pariyem.

"Iya aku tahu, itu judi buntut. Tapi kan selama ini mas Marno tidak pernah main secara besar-besaran" aku mencoba membela Marno.

$$
\text { “Sabar...Yem! Elleng Yem!” }
$$

“Bagaimana tidak sabar, wong.... Mas Marno selama ini lebih getol ngurusi kertas-kertas itu daripada diriku", Pariyem tersungut sungut menahan tangis (Boenna, 1998: VI).

Dalam kutipan tersebut, pengarang menceritakan suasana kampung dengan aktivitas sehari-hari. Alur yang digunakan adalah alur campuran, yakni alur maju dan alur mundur. Awalnya tokoh utama (Buddi) menceritakan kebiasaan sahabatnya (Marno) yang sering bermain buntut. Kemudian, cerita berganti menjadi alur mundur yang juga menceritakan masa muda, sama-sama disibukkan menjadi anggota karang taruna di kampung. Peristiwa lain, Marno bercerita ketika ia menikahi gadis kampung, kembang desa bernama Pariyem, sehingga mereka hidup bahagia. Pada klimaksnya pengarang mengambarkan kehidupan Marno yang porak-poranda akibat ulahnya sendiri. Marno telah menghancurkan masa depan dan pernikahannya akibat kecanduan bermain buntut. Tidak hanya itu, Marno juga kehilangan akal sehatnya menjadi gila.

\subsection{Nilai Moral}

Nilai moral dalam karya sastra mencerminkan pandangan hidup pengarang tentang kebenaran untuk disampaikan kepada pembaca, baik bersifat toleransi, disiplin, kerja keras, mandiri, keyakinan, dan sebagainya. Semua itu tidak terlepas dari pandangan yang dianut pengarang. Dengan kata lain, nilai moral sebagai saran atau petunjuk agar pembaca memberikan tanggapan atau mengikuti pikiran pengarang. Pesan moral dalam karya sastra dititikberatkan pada kodrat manusia yang hakiki, bukan pada aturan yang dibuat oleh manusia. Berkaitan dengan hal itu, nilai moral dalam keempat cerpen terbitan surat kabar Manuntung periode 1988 disampaikan pengarang dengan sikap dan cara pandang yang berbeda-beda. Sikap dan pan- 
dangan yang dituangkan pengarang dalam cerpen itu diharapkan dapat tersampaikan dan diterima dengan baik oleh pembaca. Adapun nilai moral dalam cerpen (1) "Dermaga Biru", (2) "Di Atas Tempaan Lalah", (3) "Dari Sebuah Kegagalan", dan (4) "Buntut" dapat diuraikan sebagai berikut.

\subsubsection{Cerpen "Dermaga Biru"}

Nilai moral yang diceritakan pengarang dalam cerpen "Dermaga Biru" adalah (1) kegelisahan tokoh Yudhi pada saat menantikan seseorang yang akan tiba di Dermaga Biru sangat berbeda dengan tokoh Bapak. Yudhi yang menantikan gadis pujaannya tampak gelisah, sedangkan sang Bapak yang menantikan anak gadisnya penuh keceriaan. Namun, keduanya duduk dan senda gurau bersama hingga yang dinantikan muncul dihadapannya, (2) kebisingan di sebuah dermaga tidak dapat dikendalikan lagi. Pelabuhan yang terletak di Kota Samarinda itu selalu dipenuhi oleh bermacam-macam orang, baik penumpang kapal maupun penjemput. Bahkan, banyak pula petugas dan jasa angkut barang. Semua membaur menjadi satu, (3) pertemuan Yudhi dengan kekasih membuatnya terperanjak kaget. Ia tidak menyangka kekasihnya itu adalah anak Pak Bondang, teman senda guraunya selama berada di Dermana Biru yang akhirnya akan menjadi orang tuanya juga.

Dalam cerpen ini, pengarang menggambarkan sekelompok orang yang bersifat acuh tak acuh, tidak peduli satu dengan lainnya. Setiap hari mereka disibukkan dengan aktivitas di dermaga. Perahu ketinting yang penuh penumpang saling bersalipan sambil terus berayun-ayun di atas riak ombak. Pengemudi tertawa-tawa dan saling senyum satu sama lain, seolah-olah tidak ada duka dan maut bagi mereka. Di sisi lain, pertemuan tokoh Yudhi dan tokoh Bapak pada saat menantikan seseorang yang didambakannya mencerminkan gejolak perasaan yang tumbuh tanpa disadari oleh dirinya. Artinya, segala sesuatu yang dilakukan dengan penuh kesabaran dan keiklasan akan menghasilkan kebaikan dan kebahagiaan. Itulah kebahagiaan yang dirasakan oleh tokoh Yudhi, sang Bapak, dan kekasihnya.

\subsubsection{Cerpen "Di Atas Tempaan Lelah"}

Nilai moral yang diceritakan pengarang dalam cerpen "Di Atas Tempaan Lelah" adalah (1) kegelisahan seorang tokoh bernama Dyera dalam menghadapi perubahan status sosial sebelumnya sebagai siswa sekolah menengah beralih menjadi mahasiwa. Kesulitan yang dihadapi Dyera bukan berasal dari perubahan satus sosial tersebut, melainkan ketidakmampuan dirinya menghadapi situasi seorng diri, (2) ketakutan yang dialami Dyera itu muncul pada saat tidak berdaya menghadapi berbagai peristiwa. Peristiwa itu berupa rasa takut, gelisah, dan ketidakmampuan menghadapi permasalahan yang ada di lingkungan perkemahan. Tokoh utama dalam cerpen ini seorang gadis manja dan cengeng. Ia merasa tidak kuat menghadapi persoalan hidup ketika berjauhan dengan keluarganya terutama Ibu dan kakaknya yang selalu memanjakannya, (3) kedewasaan mulai tumbuh di diri Dyera pada saat bertemu dengan seorang lelaki bernama Daniel. Sejak bersama Daniel, Dyera mampu mengubah diri menjadi perempuan mandiri, tangguh, disiplin, dan tanggung jawab.

Dalam cerpen ini, pengarang menunjukkan adanya perubahan karakter seseorang menjadi lebih baik lagi. Di sini, pengarang mengemas akhir cerita dengan penyelesaian masalah, yakni membangkitkan semangat tokoh utama dari keterpurukan dalam menghadapi berbagai peristiwa melalui tokoh Daniel, pemuda idaman Dyera. Kepasrahan itu adalah momok bagi diri dan lingkungan. Untuk itu, pertahankanlah 
segala kebaikan. Sebaliknya, tinggalkan kebiasaan buruk.

\subsubsection{Cerpen "Dari Sebuah Kegagalan"}

Nilai moral yang diceritakan pengarang dalam "Dari Sebuah Kegagalan" adalah (1) kegagalan tokoh Ara melanjutkan pendidikan tinggi meraih impiannya menjadi seorang yang sukses telah meruntuhkan semangat hidupnya. Seorang sahabat yang berperan sebagai protagonis telah menyadarkannya untuk bangkit melawan kegagalan, (2) kerapuhan yang dialami Ara mengakibatkan dirinya terombang-ambing dalam ketidakpastian, dan (3) kebimbangan yang dialami Ara sering muncul ketika ia teringat pada kedua orang tua yang sangat mengharapkan kesuksesannya. Karena faktor itulah, Ara mulai bangkit dari keterpurukan dan berusaha meraih kesuksesan.

Dalam cerpen ini, pengarang mengilustrasikan sebuah kegagalan, kerapuhan, dan kesuksesan. Kegagalan dan kerapuhan yang dialami tokoh Ara merupakan pelajaran dan pengalaman hidup yang harus dilaluinya. Sementara itu, kesuksesan yang diraih Ara adalah pembuktian bahwa seorang perempuan tidak dapat dipandang lemah dan tidak berdaya. Tokoh Ara membuktikan kemampuannya untuk melawan dan mengatasi sebuah kegagalan dan kerapuhan tanpa kehilangan semangat meraih kesuksesan. Nilai-nilai karakteristik seseorang dengan berbagai dinamika kehidupan seperti yang dialami tokoh Ara itu muncul karena faktor kondisi sosial, ekonomi, dan budaya. Hal itu dapat terjadi di lingkungan sosial masyarakat pada umumnya.

\subsubsection{Cerpen "Buntut"}

Nilai moral yang digambarkan pengarang dalam cerpen "Buntut" adalah (1) ketidakberdayaan tokoh Marno diperbudak hasratnya untuk terus bermain buntut. Sifat bijaksana yang dimilikinya seketika dilumpuhkan oleh keegoisan dan keserakahannya. Marno seorang yang diteladani dan menjadi panutan teman-temannya, justru tidak berdaya melawan kebiasaan buruk bermain judi, (2) kehancuran rumah tangga tidak mampu menyadarkan Marno untuk terus bermain buntut. Nasihat sahabat, Mbok Ijah, dan istrinya tidak pernah diperdulikan. Marno menjadi pribadi yang rapuh setelah ditinggalkan istri yang sangat dicintainya, dan (3) penderitaan yang dialami oleh Marno mengakibatkan kehilangan akal sehatnya. Marno menderita guncangan jiwa, pikirannya tidak normal lagi. Kebiasaan bermain buntut atau judi telah menghancurkan kehidupan Marno dan dan keluarganya. Marno yang awalnya memiliki kepribadian tangguh, kuat, mandiri, dan penuh tanggung jawab terhadap keluarga dan organisasinya, seketika berubah menjadi rapuh dan menyerah pada kenyataan yang sedang dialaminya. Dalam Cerpen ini pengarang ingin menyampaikan bahwa setiap kebiasaan buruk yang dilakukan tidak akan menghasilkan kebaikan. Hal itulah yang terjadi pada tokoh Marno. Kegemaran bermain judi dan togel yang dialami tokoh Marno dalam cerpen "Buntut" merupakan potret kehidupan sosial yang terjadi di kalangan masyarakat umum, baik di perkotaan maupun pedesaan. Permainan judi atau buntut tidak membuat seseorang menjadi bahagia, justru akan menghancurkan diri dan lingkungannya.

\section{PENUTUP}

Keberadaan sastra Indonesia di Kalimantan Timur masih memanfaatkan media massa sebagai publikasi. Kemunculan cerpen dimulai sejak terbitnya harian Manuntung dan media massa lainnya, seperti Meranti, Kaltim Post, Suara Kaltim, Samarinda Post, Membangun Bumi Etam, dan Tribun Kaltim. Sejumlah media massa tersebut mampu menerbitkan karya sastra, di antaranya prosa, puisi, cerpen, drama, dan sebagainya. Surat kabar harian Manuntung 
merupakan surat kabar yang menampilkan cerita pendek yang ditulis oleh pengarang Indonesia di wilayah Kalimantan Timur. Cerpen-cerpen dalam surat kabar Manuntung periode 1988 memiliki keragaman tema, karakter, realita sosial, masalah keluarga, dan percintaan. Sementara itu, nilai-nilai moral yang terjadi merupakan pesan tidak langsung dari pengarang. Untuk itu, pendeskripsian struktur intrinsik dan ekstrinsik dalam keempat cerpen terbitan di surat kabar harian Manuntung periode 1988 ini lebih difokuskan pada tema dan nilai-nilai moral.

Cerpen "Dermaga Biru" mengangkat tema penantian seorang pemuda pada kekasih dan orang tua pada anaknya. Kedua lelaki tua dan lelaki muda itu menantikan kedatangan orang di sebuah Dermaga Biru. Alur yang digunakan adalah alur maju dengan latar belakang kondisi sosial budaya masyarakat perkotaan yang tinggal di tepian Sungai Mahakam. Pada akhir cerita pengarang menyelesaikannya dengan kebahagiaan. Kedua lelaki itu menyambut kedatangan seseorang yang sudah lama didambakannya. Nilai moral yang disampaikan pengarang dalam cerpen ini mengisyaratkan bahwa setiap penantian, harapan, dan hasrat terpendam dengan sendirinya akan tiba dan membuahkan hasil yang membahagiakan.

Cerpen "Di Atas Tempaan Lelah" mengangkat tema sebuah kegelisahan dan pengharapan. Dyera adalah gadis manis, manja, dan sangat bergantung pada Ibu dan kakaknya. Alur yang digunakan adalah alur maju dan diselingi dengan peristiwa kilas balik untuk mengenang ingatan pada tokoh lawan. Pertemua Dyera dengan lelaki impiannya, telah mengubah dirinya menjadi gadis mandiri. Nilai moral yang ingin disampaikan pengarang adalah sebuah pelajaran bahwa jangan selalu menggantungkan keinginan dan harapan pada pihak lain, akibatnya akan rapuh, lemah, dan tidak percaya diri. Sebaliknya, jika bijaksana dalam menghadapi permasalahan, seseorang akan menjadi lebih baik dalam menyikapi kehidupan di sekitarnya.

Cerpen "Dari Sebuah Kegagalan" mengangkat tema kegagalan. Tema ini diawali dari keputusasaan seorang gadis yang ingin meraih harapan dan impiannya. Selepas SMA, tokoh utama (Ara) berkeinginan melanjutkan pendidikan ke perguruan tinggi negeri. Namun, yang diperoleh Ara hanya sebuah kegagalan. Alur yang digunakan dalam cerita ini adalah alur maju. Nilai moral yang ingin disampaikan pengarang adalah ketidakberdayaan yang dialami seseorang itu bukanlah sebuah kegagalan yang harus dipasrahkan begitu saja. Sebaliknya, kegagalan merupakan harapan untuk meraih kesuksesan. Kondisi psikis seseorang seperti yang dialami Ara itu dapat terjadi pada masyarakat umum di lingkungan sosial dan budaya yang mendukungnya.

Cerpen "Buntut" mengangkat tema sosial. Tema ini diawali dengan kebiasaan seorang lelaki yang hobi bermain judi, buntut, atau togel. Marno memiliki kepribadian sosial, disiplin, dan bertanggung jawab. Namun, kebiasaan bermain buntut telah menghancurkan dirinya. Bahkan, rumah tangganya turut hancur. Tidak hanya itu, Marno juga kehilangan akal sehatnya menjadi gila. Alur yang digunakan adalah alur campuran, yakni alur maju dan alur mundur. Nilai moral yang disampaikan pengarang dalam cerpen ini adalah kehancuran yang dialami seseorang akibat kebiasan buruk tentu saja akan merugikan diri sendiri dan membawa kehancuran pada nilai-nilai kehidupan.

Secara keseluruhan, keempat cerita pendek terbitan surat kabar Manuntung di Kalimantan Timur menggambarkan kehidupan masyarakat umum dengan ber- 
bagai peristiwa yang dialami oleh tokohtokoh dalam cerpen. Tema dalam keempat cerpen itu memiliki perwatakan dan karakteristik penceritaan yang berbeda. Dalam cerpen-cerpen tersebut, pengarang memiliki cara pandang dan sikap yang berbeda pula ketika mengisahkan sebuah peristiwa dan pengalaman tokoh dengan berbagai konflik dan penyelesaiannya. Sementara itu, nilainilai moral dalam keempat cerpen itu merupakan cerminan kehidupan yang dialami masyarakat umum dengan latar, waktu, dan lingkungan tertentu yang melatarbelakangi terjadinya peristiwa dalam cerita itu. Semua peristiwa yang diilustrasikan pengarang dalam cerpen-cerpen terbitan surat kabar Manuntung periode 1988 terjadi di lingkungan sosial dan budaya Kalimantan Timur.

\section{DAFTAR PUSTAKA}

Birawono, Iin E. Cerpen "Di Atas Tempaan Lalah". Balikpapan: Terbitan Harian Manuntung. (Rabu, 12 Oktober 1988 halaman VI).

Boenna, Roedy Rachmaddi Masykoer.

Cerpen "Buntut". Balikpapan: Terbitan Manuntung. (Rabu, 28 Desember 1988 halaman VI).

Departemen Pendidikan Nasional. 2008. Kamus Besar Bahasa Indonesia (KBBI), Edisi Keempat. Jakarta: Balai Pustaka.

Effendy, Chairil. 2011. "Sastra Modern di Kalimantan Barat: Dahulu dan Kini" dalam Korrie Layun Rampan. Sumbangan Borneo Kalimantan terhadap Sastra Indonesia, Brunei Darussakam, dan Malaysia. Yogyakarta: Araska Printika.
Herawati, Yudianti 2020. “Tema Percintaan dalam Tiga Cerita Pendek Terbitan Surat Kabar Manuntung di Kalimantan Timur (Periode 1988-1989)" dalam Jurnal LOA Ketatabahasaan dan Kesusatraan. Volume 15 Nomor 2, Desember 2020. Halaman 93-181. Samarinda: Kantor Bahasa Provinsi Kalimantan Timur.

Larisya, Ifta. Cerpen "Dari Sebuah Kegagalan". Balikpapan: Terbitan Harian Manuntung. (Kamis, 3 November 1988 halaman VI).

Nurgiyantoro, Burhan. 2013. Teori Pengkajian Fiksi. Yogyakarta: Gadjah Mada University Press.

Rahmanto, B. 1988. Metode Pengajaran Sastra. Yogyakarta: Kanisius.

Rampan, Korrie Layun. 2011. “Kalimantan Timur dalam Sastra Indonesia" dalam Korrie Layun Rampan. Sumbangan Borneo Kalimantan terhadap Sastra Indonesia, Brunei Darussakam, dan Malaysia. Yogyakarta: Araska Printika.

Stanton, Robert. 2012. Teori Fiksi. Yogyakarta: Pustaka Pelajar.

Wahyudi, Sukardi. Cerpen "Dermaga Biru”. Balikpapan: Terbitan Harian Manuntung. (Kamis, 21 Juli 1988 halaman VI).

Wicaksono, Andri. 2014. Pengkajian Prosa Fiksi. Yogyakarta: Garudhawaca. 